\title{
EXPERIMENTAL INVESTIGATION ON PROPERTIES OF CONCRETE WITH ALCCOFINE1203 AS PARTIAL REPLACEMENT OF CEMENT SUBJECTED TO DIFFERENT CURING REGIMES
}

\author{
NISTA LAMA GHISING ${ }^{1} \&$ VIJAY KUMAR ${ }^{2}$ \\ ${ }^{I}$ ME Student, Department of Civil Engineering, Chandigarh University, Mohali, Punjab, India \\ ${ }^{2}$ Assistant Professor, Department of Civil Engineering, Chandigarh University, Mohali, Punjab, India
}

\begin{abstract}
In this paper, an experimental investigation is conducted to study the changes in the physical properties of concrete when alccofine 1203 is used in the concrete mix as a partial substitute for cement. This paper also aims at studying the effect in the properties of concrete mix that are caused when it is subjected to different types of curing regime. For this study, concrete mix of M35 grade is prepared and the proportion of alccofine in the concrete mix as a substitute material for cement is gradually increased at a rate of $5 \%$ i.e, concrete mix with $0 \%, 5 \%, 10 \%, 15 \%$ \& $20 \%$ alccofine measured by weight of cement. For the purpose of studying the early strength gain development, the cube samples were tested at ages of 3days, 7 days and 28 day for compressive strength while for the flexural strength the beam samples were tested at the age of 28 days. All the concrete samples made with different replacement proportions were then subjected to three different curing regimes separately. According to data obtained from this experiment, it indicates that there is overall increase in the strength of the concrete mix. Also water immersion curing gave the best results.

KEYWORDS: Alccofine 1203, Partial Replacement, Alccofine Concrete, Curing Regime
\end{abstract}

Received: Jun 10, 2020; Accepted: Jun 30, 2020; Published: Jul 21, 2020; Paper Id.: IJMPERDJUN2020404

\section{INTRODUCTION}

In cement plants, the magnitude of $\mathrm{CO}_{2}$ released during its manufacturing process is very high effectuating to a substantial need for lowering down the quantity of cement consumption in the construction industries and thus, catalyse for the search of alternate materials as cement substitute. With the advancement of time, there is high demand for concrete with enhanced properties and high performance fostering to the incorporation of additives in concrete. Curing plays an important factor in concrete strength development and durability of concrete.

\section{Alccofine 1203}

Alccofine is an ultrafine sized material with blaine value of $12000 \mathrm{~cm} 2 / \mathrm{gm}$. The raw material of alccofine is slag of high glass content with high reactivity obtained through the process of controlled granulation in addition to that controlled conditions are maintained with special equipments during its manufacturing process to produce optimized particle size distribution which is its distinctive attribute. According to previous studies, alccofine owing to its ultrafine particle size distribution and chemical constitution can be possibly utilized as a workability aid. Previous results also show that the incorporation of alccofine in the concrete mix enhances its properties.

So in this paper, it puts forward an attempt to study the changes in physical properties of concrete when alccofine 1203 is used in the concrete mix as a partial substitute for cement and is subjected to different regimes. 


\section{METHODOLOGY}

\section{Properties of Material Used}

Table 1: Cement Properties

\begin{tabular}{|c|l|c|}
\hline Serial No. & \multicolumn{1}{|c|}{ Properties } & Values \\
\hline 1 & Cement & OPC \\
\hline 2 & OPC Grade & 43 \\
\hline 3 & Normal Consistency & $30.5 \%$ \\
\hline 4 & Specific Gravity & 3.3 \\
\hline 5 & $\begin{array}{l}\text { Setting Time of Cement } \\
\text { I. Initial Setting Time }\end{array}$ & $29 \mathrm{~min}$ \\
& II. Final Setting Time & min \\
\hline
\end{tabular}

Table 2: Aggregate Properties

\begin{tabular}{|c|l|c|}
\hline Serial No. & \multicolumn{1}{|c|}{ Properties } & Values \\
\hline 1 & Specific Gravity of Fine Aggregates & 2.6 \\
\hline 2 & Specific Gravity of Coarse Aggregates & 2.67 \\
\hline 3 & Fineness Modulus of Fine Aggregate & 3.12 \\
\hline 4 & Fineness Modulus of Coarse Aggregate & 8.09 \\
\hline
\end{tabular}

Table 3: Alccofine1203 Physical Properties

\begin{tabular}{|c|l|c|}
\hline Serial No. & Properties & Magnitude \\
\hline 1 & Bulk Density & $600-700 \mathrm{~kg} / \mathrm{m}^{3}$ \\
\hline 2 & Fineness & $>12000 \mathrm{~cm}^{2} / \mathrm{gm}$ \\
\hline 3 & Particle Shape & Irregular \\
\hline 4 & Particle Size, $\mathrm{d}_{10}$ & $<2 \mu$ \\
\hline 5 & Particle Size, $\mathrm{d}_{50}$ & $<5 \mu$ \\
\hline 6 & Particle Size, $\mathrm{d}_{90}$ & $<9 \mu$ \\
\hline
\end{tabular}

Table 4: Chemical Properties of Alccofine 1203

\begin{tabular}{|c|c|c|}
\hline Serial No. & Compound & Range \\
\hline 1 & $\mathrm{CaO}$ & $32 \%-34 \%$ \\
\hline 2 & $\mathrm{SiO}_{2}$ & $33 \%-35 \%$ \\
\hline 3 & $\mathrm{SO}_{3}$ & $0.3 \%-0.7 \%$ \\
\hline 4 & $\mathrm{MgO}$ & $8 \%-10 \%$ \\
\hline 5 & $\mathrm{Fe}_{2} \mathrm{O}_{3}$ & $1.8 \%-2 \%$ \\
\hline 6 & $\mathrm{Al}_{2} \mathrm{O}_{3}$ & $18 \%-20 \%$ \\
\hline
\end{tabular}

\section{Experimental Work}

- Mix Design and Proportion: For this experiment, mix design was prepared as per IS 10262: 2019 for M35 grade concrete. And the concrete mix proportion used was1:1.6:2.92 with water cement ratio taken as 0.38.

- Preparation of Concrete Mix Specimens: The dimensions of cube and beam specimens used are $150 \times 150 \times 150 \mathrm{~mm}$ and $100 \times 100 \times 500 \mathrm{~mm}$ respectively. For compressive strength test, cubed were casted for $7 \&$ 28 day test, in addition to which 3 day test was also added to check for early strength and in case of flexural strength test casting was done for 28 day test. Three different sets of specimens were prepared for the three different curing regimes i.e. water immersion curing, polythene sheet curing and burlap curing. A total of 180 specimens were made with 60 specimens for each curing regime. Each set contain 60 specimens (45 cubes and 15 beams) where alccofine is used as partial substitute material for cement in $0 \%-20 \%$ i.e. $(0,5,10,15 \& 20 \%)$ respectively by weight of cement. 
- Curing of Specimen: After removing the cast the specimens were cured separately in the different arrangements made as per the curing regime it is subjected to. The first sets of specimens were immersed in curing tanks filled with water. Second set of specimens were covered with hessian bags (gunny bags) after which the hessian bags were wetted with water throughout the curing period. The third set of specimens were wrapped with polythene sheet and sealed completely until testing. The specimens were left undisturbed for the whole curing period.

\section{TESTING AND RESULT}

\section{Compression Test Results}

The test samples with different proportions of alccofine, subjected to various curing regime gave the following results for compression strength test.

Table 5: Compression Test Results for Cube Specimens

\begin{tabular}{|c|c|c|c|c|c|c|c|c|c|c|}
\hline \multirow{3}{*}{ Sl. No. } & \multirow{2}{*}{$\begin{array}{c}\text { Alccofine (\%) } \\
\text { by Weight of } \\
\text { Cement }\end{array}$} & \multicolumn{9}{|c|}{ Compression Strength Results (in N/mm2) } \\
\cline { 3 - 13 } & & Water Immersion Curing & \multicolumn{2}{c|}{ Polythene Sheet Curing } & \multicolumn{3}{|c|}{ Burlap Curing } \\
\cline { 3 - 12 } & 3 Day & 7 Day & 28 Day & 3 Day & 7 Day & 28 Day & 3 Day & 7 Day & 28 Day \\
\hline 1 & $0 \%$ & 17.8 & 26.49 & 35.9 & 17.2 & 25.77 & 35.2 & 17.4 & 24.8 & 35.5 \\
\hline 2 & $5 \%$ & 20.3 & 27.12 & 37.3 & 20.9 & 28.35 & 36.2 & 20.1 & 26.6 & 36.32 \\
\hline 3 & $10 \%$ & 24.4 & 34.02 & 39 & 23.8 & 30.9 & 37.3 & 22.9 & 29.67 & 37.2 \\
\hline 4 & $15 \%$ & 22.7 & 32.81 & 41 & 21.6 & 29.70 & 38.1 & 21.8 & 31.88 & 39.6 \\
\hline 5 & $0 \%$ & 19.8 & 28.34 & 38.8 & 20.9 & 27.32 & 36.6 & 19.3 & 26.37 & 38.3 \\
\hline
\end{tabular}

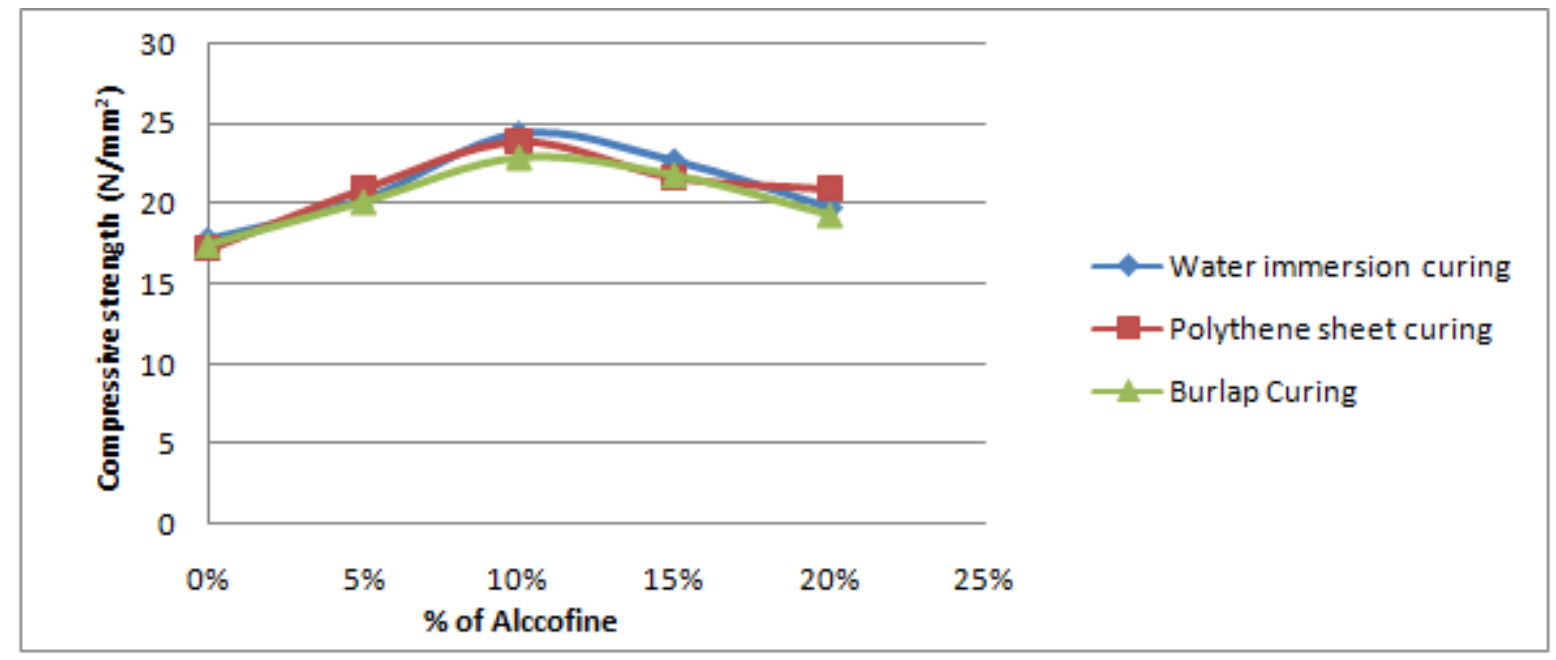

Figure 1: Variation in Compressive Strength (3 Day Test Result). 


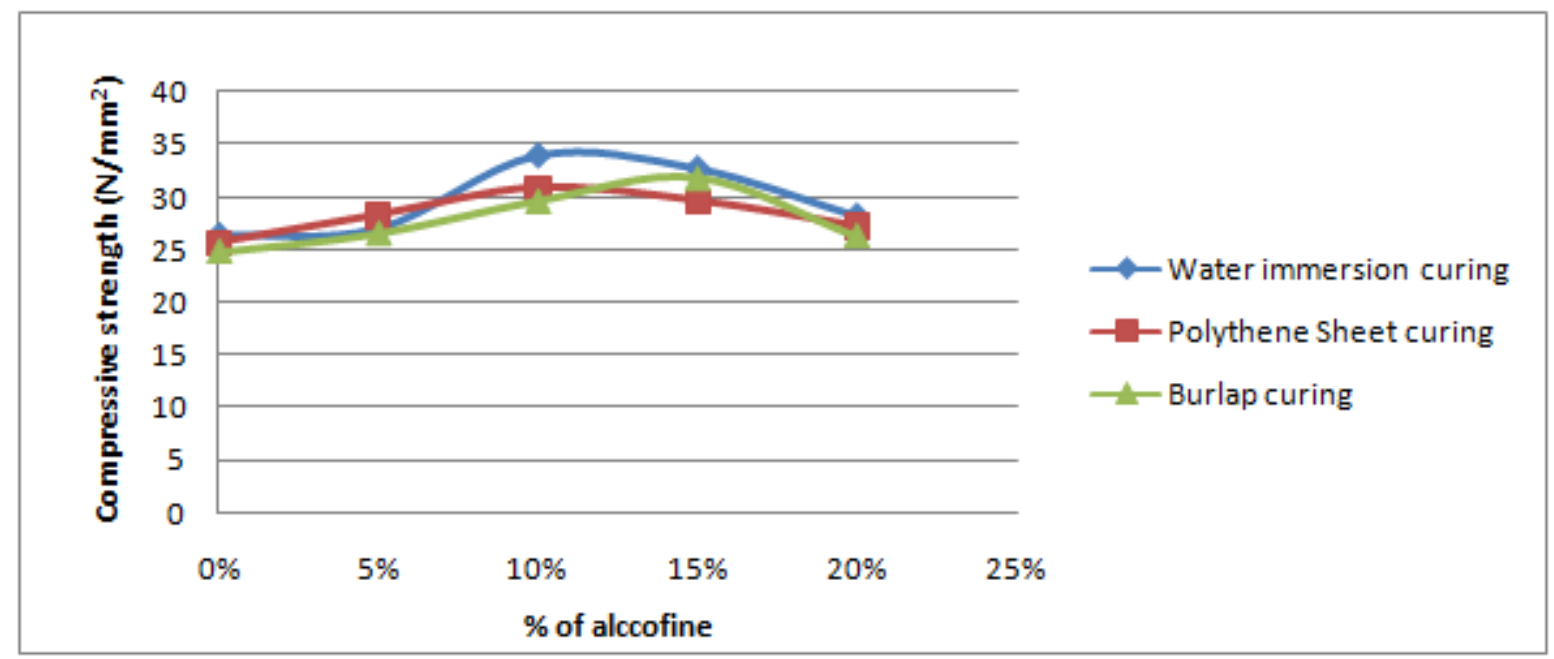

Figure 2: Variation in Compressive Strength (7 Day Test).

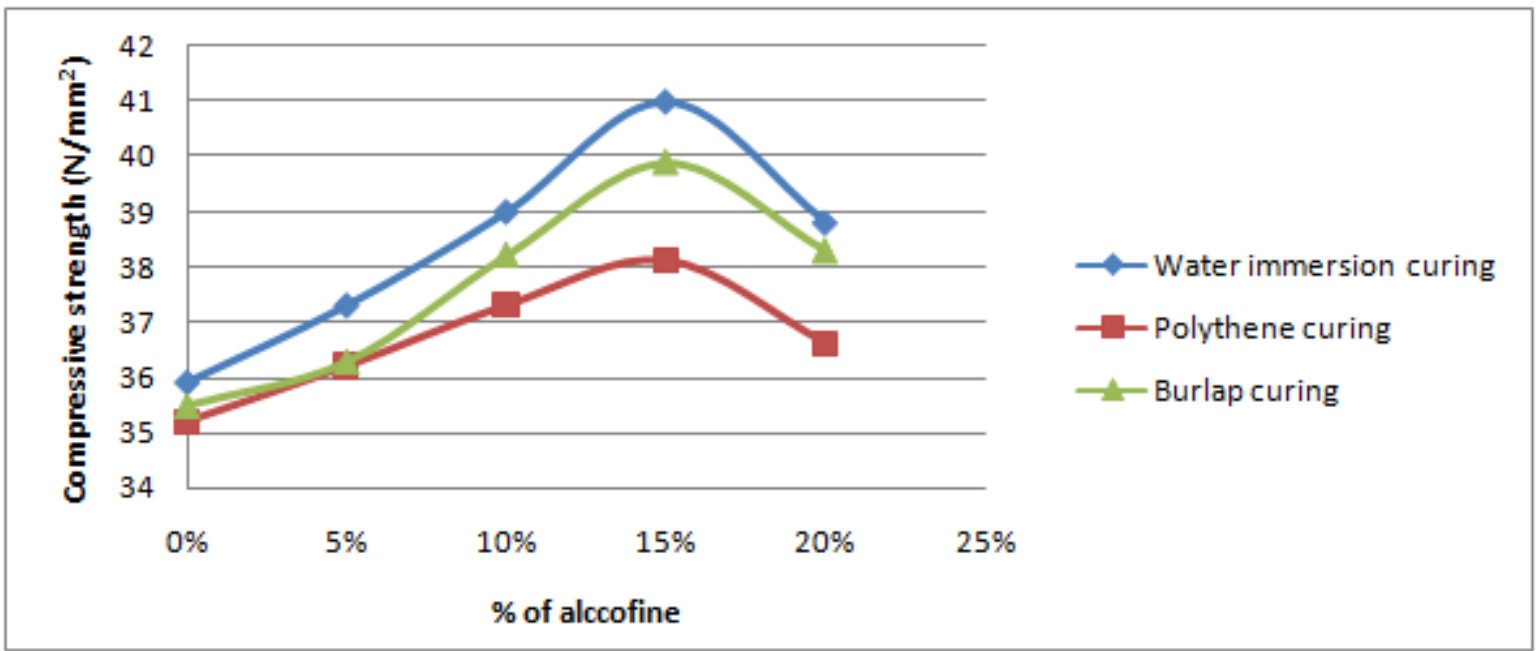

Figure 3: Variation in Compressive Strength (28 Day Test).

Flexural Test Results

Table 6: Results for Flexural Test in Beam Specimens

\begin{tabular}{|c|c|c|c|c|}
\hline \multirow{2}{*}{ Serial No. } & \multirow{2}{*}{$\begin{array}{c}\text { Alccofine (\%) by Weight of } \\
\text { Cement }\end{array}$} & \multicolumn{3}{|c|}{ Flexural Strength (in) for 28 Days } \\
\cline { 3 - 5 } & & $\begin{array}{c}\text { Water Immersion } \\
\text { Curing }\end{array}$ & $\begin{array}{c}\text { Polythene Sheet } \\
\text { Curing }\end{array}$ & $\begin{array}{c}\text { Burlap } \\
\text { Curing }\end{array}$ \\
\hline 1 & $0 \%$ & 7.1 & 6.9 & 7 \\
\hline 2 & $5 \%$ & 8.8 & 7.9 & 8.3 \\
\hline 3 & $10 \%$ & 9.2 & 8.6 & 9.02 \\
\hline 4 & $15 \%$ & 9 & 8.4 & 8.7 \\
\hline 5 & $20 \%$ & 8.3 & & 8.4 \\
\hline
\end{tabular}




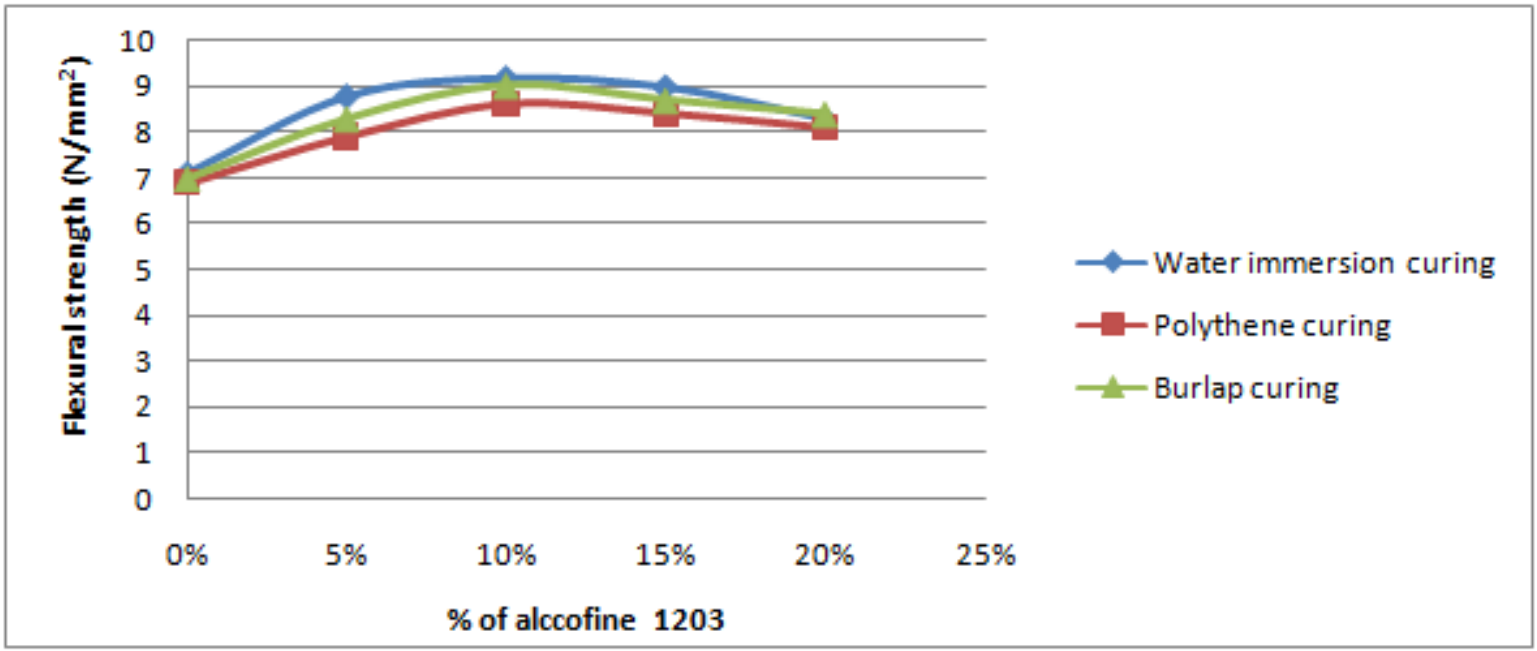

Figure 4: Variation in Flexural Strength (28 Day Test).

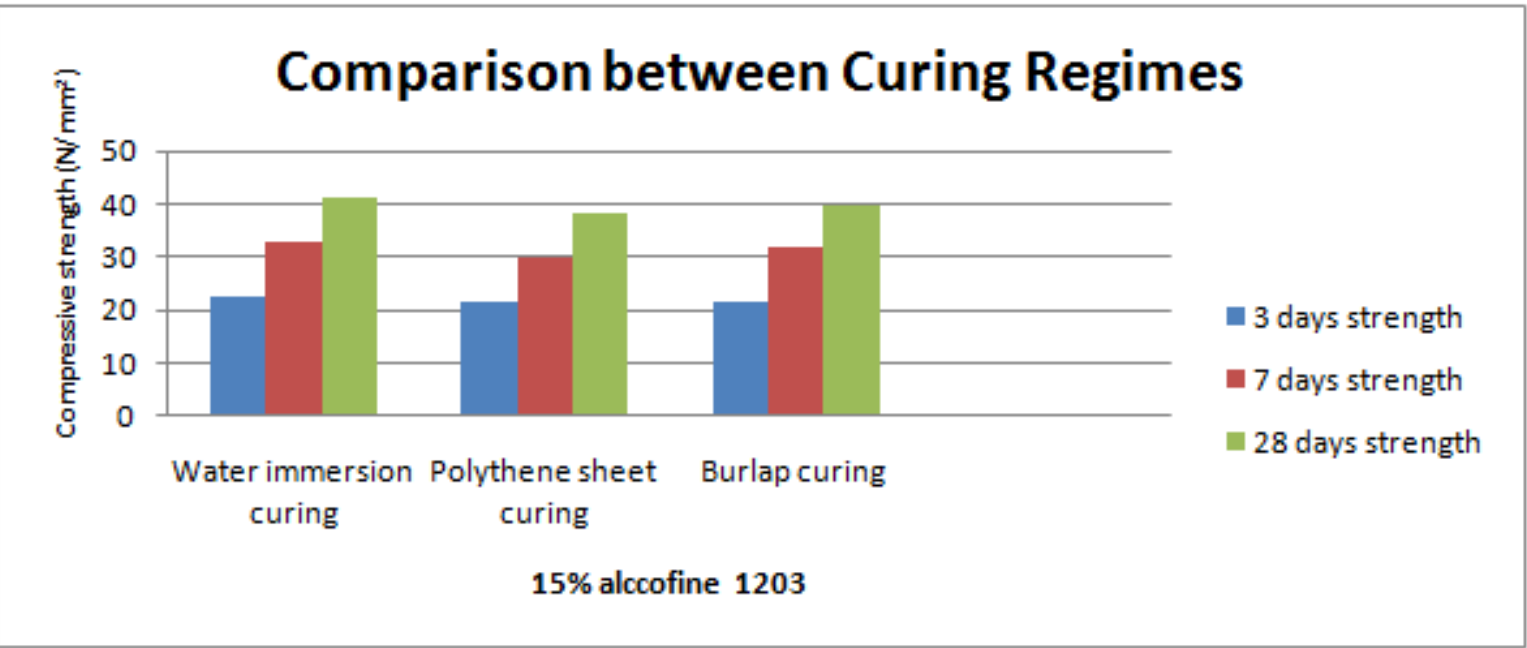

Figure 5: Comparison between the Three Different Curing Regimens on the Basis of Compressive Strength (15\% Alccofine).

\section{CONCLUSIONS}

- From the results obtained, $15 \%$ partial substitution of cement with alccofine gave the highest value of compression test results whereas for flexural strength test, it was found to be $10 \%$. Therefore, the optimum partial replacement percentage were found to be $15 \%$ (Compressive strength) and 10\% (Flexural strength).

- The incorporation of alccofine 1203 in the concrete mix induces early strength gaining properties in all mix proportions

- From this study it was observed that water immersion curing gives the best results followed by burlap curing.

- The water immersion curing gave overall maximum results at all ages.

- Therefore, by partially substituting $15 \%$ of cement with alccofine gives an increment of $17.14 \%$ in compressive strength while for flexural strength, $10 \%$ of alccofine gives an increment of $29.57 \%$. 


\section{REFERENCES}

1. Narinder Reddy\& T. Meena,2017,An Experimental investigation on mechanical behaviour of Eco-friendly Concrete, IOP conference Series: Materials Science and Engineering, Vol. 263, pp. 1-9

2. Balamuralikrishnan R. \& Saravanan J.,2019, Study on Bond Strength of Alccofine Based Normal and High Strength Concrete, Civil Engineering Journal, Vol. 5, No. 3,pp 679-698

3. Jangra P.,Singhal D., Junaid, M.T.\& Jindal, B.B., 2018. Mechanical and microstructural properties of fly ash based geopolymer concrete incorporating alccofine at ambient curing. Construction and Building Materials, 180, pp.298-307.

4. P. R. Kalyana Chakravarthy \& R. Rathan Raj,2017, analysis on compressive strength of concrete with partial replacement of cement with alccofine, ARPN Journal of Engineering and Applied Sciences, VOL. 12, NO. 8.

5. P. Narasimha Reddy \& J. Ahmed Naqash, 2019, Development of high early strength in concrete incorporating alccofine and non-chloride accelerator. SN Applied Sciences, 1(7), p.755.

6. Pavittar Singh, 2017,study the effect of alccofine on development of high strength concrete, Intenational Journal of Advanced Research in Science and Engineering, Vol .5 No 11,pp 1985-1992

7. IS 8112:2013. (2013). Ordinary Portland Cement, 43 Grade.Indian Standard .

8. IS 10262-2019. (2019). Concrete Mix Proportioning .Indian Standard.

9. IS 383:2016. (2016). Coarse and fine aggregate for concrete.Indian Standard.

10. IS 9103:1999. (1999). Specification for Concrete Admixtures.Indian Standard.

11. Alccofine by Counto Micro fine Products Pvt. Ltd.

12. M. Vijaya Sekhar Reddy, K. Ashalatha \& K. Surendra, 2016,Studies on eco-friendly concrete by partial replacement of cement with Alccofine and fine Fly ash, ARPN Journal of Engineering and Applied Sciences, Vol. 11, Issue 5, Page no. 3445-3448

13. S. Kavitha \& T. Felix Kala, 2016,Evaluation of Strength Behavior of Self-Compacting Concrete using Alccofine and GGBS as Partial Replacement of Cement, Indian Journal of Science and Technology, Vol. 9, Issue 22, Page No. 1-5.

14. Devinder Sharma, Sanjay Sharma \& Ajay Goyal, 2016, Utilization of Waste Foundry Slag and Alccofine for Developing High Strength Concrete, International Journal of Electrochemical Science, Vol. 11, Issue 1, Page No. 3190 - 3205.

15. K. Gayathri, K. Ravichandran \&J. Saravanan,2016,Durability and cementing efficiency of Alccofine in concretes, International Journal of Engineering Research \& Technology, Vol. 5, Isssue 5, Page No. 460-467.

16. D.Sivakumar, T. Hemalatha, N. Shakthi Sri, T. Shobana, C. Soundarya,2015,Durability and Mechanical Characterization of Concrete Using Alccofines, International Journal of Applied Engineering Research, Vol. 10 No.53,pp 178-182

17. Ansari U.S, Chaudhri I.M, Ghuge N.P and Phatangre R.R, 2015,High Performance Concrete with Partial Replacement of Cement by Alccofine \& Fly ash, Indian Research Transaction, Vol. 5, Issue 2, Page No.19-23.

18. D. Sivakumar, T. Hemalatha, N. Shakthi Sri, T. Shobana and C. Soundarya,2015 ,Durability and Mechanical Characterization of Concrete Using Alccofines, International Journal of Applied Engineering Research, Vol. 10,Issue 24, Page No. 178-183

19. V. Umamaheswaran, C. Sudha, P. T. Ravichandran and P. R. Kannan Rajkumar, 2015, Use of M Sand in High Strength and High Performance Concrete, Indian Journal of Science and Technology, Vol. 8, Issue 28, Page No. 1-8. 
20. Kumar RS, Samanta A K, Singha Roy D K, 2015,An experimental study on the mechanical properties of Alccofine based high grade concrete, International Journal of Multidisciplinary Research and Development, Volume:2, Issue: 10,pp 218-224

21. Mahammedtofik Y. Patel, A.R.Darji and B.M.Purohit, 2015,Study on Mechanical properties of High Performance Concrete with alccofine and waste glass powder, International Journal of Science \& Engineering Research, Vol.6, Issue 5, Page No. 102-107.

22. D. Soni, S. Kulkarni, and V Parekh, 2013,Experiment Study on High Performance Concrete With Mixing of Alccofine and Flyash, Indian Journal of Research, Vol. 3 (4), pp. 84-86

23. Alam, Mehtab, et al. "Acceptability of demolished concrete waste aggregate in making high strength self-compacting concrete." International Journal of Civil Engineering (IJCE) 2.3 (2013): 1-12.

24. Patel, H. S., and H. S. Patel. "Effect On Compressive And Flexural Strength Of High-Performance Concrete Incorporating Alccofine And Fly Ash." International Journal of Civil, Structural, Environmental and Infrastructure Engineering Research and Development (IJCSEIERD) 3.2 (2013): 109-114.

25. Dahmani, M., and A. Tafraoui. "Investigation to Improve the Sand Molding Formula of the Erg by Incorporating Local Materials." International Journal of Mechanical and Production Engineering Research and Development (IJMPERD) 8.4 (2018):517-530

26. Aziz, Omar Q., and Bahman O. Taha. "Mechanical properties of high strength concrete (HSC) with and without chopped carbon fiber (CCF)." International journal of civil engineering (IJCE), 2.1 (2013): 1-12. 

